Original Article

\title{
POTENTIAL ROLE OF MILK THISTLE SEED AND ITS OIL EXTRACTS AGAINST HEART AND BRAIN INJURIES INDUCED BY $\gamma$-RADIATION EXPOSURE
}

\author{
NOHAIR H. SHERIF', ASRAR M. HAWAS ${ }^{1}$, WALID E. ABDALLAH², IBRAHIM A. SALEH², KHALED A. SHAMS², \\ FAIZA M. HAMMOUDA ${ }^{2}$
}

1Drug Radiation Research Dept, National Centre for Radiation Research and Technology (NCRRT), Atomic Energy Authority, 3 Ahmed El Zomor St, El-Zohour Region, Nasr City, Cairo, Egypt, ${ }^{2}$ Phytochemistry Dept, National Research Centre, 33 El Bohouth St, (former El Tahrir St,), Dokki, Giza, Egypt

Email: brahim82@hotmail.com

Received: 21 Feb 2017 Revised and Accepted: 19 May 2017

\begin{abstract}
Objective: This study aimed to investigate the protective effect of Silybum marianum (S. marianum) seeds extract its oil fraction against damage effect of $\gamma$-radiation in female albino rats.

Methods: Ultrasonic-assisted extraction was used for the extraction of S. marianum seeds. Lipid patterns of S. marianum seeds oil were elucidated using gas chromatography-mass spectrometry (GC-MS). S. marianum seeds extract was analyzed using high-performance liquid chromatography (HPLC). Malondialdehyde (MDA), reduced glutathione (GSH) and metallothionein (MT) were estimated in heart and brain tissues of the examined rats. Lactate dehydrogenase (LDH) and creatine kinase-MB (CKMB) were measured in the serum of the examined rats, and the brain biomarkers; dopamine and serotonin were also measured.

Results: The oil was found to be rich in linoleic acid (58.20\%) and arachidic acid (23.38\%). S. marianum seeds extract revealed the presence of taxifolin and six main active constituents of silymarin, including silydianin, silychristin, silybin A, silybin B, isosilybin A and isosilybin B. Treatment of $\gamma$-radiation damage effect using S. marianum seeds extract and its oil fraction led to a significant reduction of MDA levels in heart (139.6 and $165.5 \mathrm{nmol} / \mathrm{g}$, respectively) and brain (158.5 and $135.2 \mathrm{nmol} / \mathrm{g}$, respectively) tissues, however, significant increase of GSH levels in heart (316.4 and $293 \mathrm{mg} / \mathrm{g}$, respectively) and brain (210.4 and $227 \mathrm{mg} / \mathrm{g}$, respectively) tissues was observed, also a significant increase of dopamine levels (85.27 and $65.74 \mathrm{ng} / \mathrm{g}$, respectively) and MT levels of heart tissues (108.5 and $70.52 \mathrm{mg} / \mathrm{g}$, respectively) was observed.
\end{abstract}

Conclusion: S. marianum seeds extract and its oil fraction showed a protective effect against $\gamma$-radiation-induced damage in heart and brain.

Keywords: Silybum marianum, $\gamma$-radiation, Heart, Brain, Female rats

(C) 2017 The Authors. Published by Innovare Academic Sciences Pvt Ltd. This is an open access article under the CC BY license (http://creativecommons.org/licenses/by/4.0/) DOI: http://dx.doi.org/10.22159/ijpps.2017v9i7.18046

\section{INTRODUCTION}

Reactive oxygen species (ROS) are a normal component of oxidative phosphorylation and play an important role in normal redox control of physiological signalling pathways. However, excessive ROS generation triggers cell dysfunction, lipid peroxidation, DNA mutagenesis and can lead to irreversible cell damage or death [1-3]. Reactive oxygen compounds may attack and damage lipids, proteins and DNA. Such effects appear to contribute in the pathogenesis of many diseases, such as central nervous system diseases, cancer, cardiovascular diseases and liver damage. Antioxidants, as flavonoids, have positive effects on preventing or attenuating these diseases [4].

Radiation exposure is an oxidative stress inducer via generation of ROS such as superoxide anions, hydrogen peroxide and hydroxyl radicals [5]. Therefore, protection of the biological systems from ionizing radiation is of paramount importance to combat radiation damages using nontoxic radio protectors. Many synthetic, as well as natural compounds, have been investigated for their efficacy to protect the biological systems against the deleterious effects of radiations $[6,7]$.

Silybum marianum L. Gaertn ( $S$. marianum) seeds (milk thistle, Asteraceae), contain an isomeric mixture of polyphenolic flavonolignans (silychristin, silydianin, silybin, and isosilybin), collectively known as silymarin [8]. Silymarin has a long history of use, it has antioxidant, antiinflammatory and antifibrotic effects in the liver $[9,10]$, and it may be used as an anticancer agent [11]. Silymarin or silybin alone showed hepatoprotection effect against iron overload [12] and chemical toxicity [13]. Also, it can enhance regeneration and metabolism of liver cells [14, 15], including bile salt production [16]. According to Prabha and coworkers [17], silibinin showed a protection effect against radiation- induced mortality and DNA damage in blood leukocytes. Also, silybin and its analogues offer different ability to repair DNA base against radiationinduced damage [18]. Silymarin may reduce oxidative stress in the brain, with potential consequences for neurodegenerative disorders and may contribute to the prevention of age-related and pathological degenerative processes in the brain [19].

The present study aimed to investigate the protective effect of $S$. marianum seeds extract or/and its oil fraction against the exposure to fractionated dose of $\gamma$-radiations.

\section{MATERIALS AND METHODS}

Plant material

S. marianum seeds were collected from the field, Beni-suif, Egypt (GPS coordinates: N29 ${ }^{\circ} 16.518^{\prime}$, E031 ${ }^{\circ} 16.5611^{\prime}$, elevation $63 \mathrm{~m}$ ), after cultivation for one year during (September 2014) and a voucher specimen (\#6411) was deposited at the National Research Centre Herbarium. Collected seeds were washed with distilled water and dried, then grinded to powder and stored for further extraction.

\section{Chemicals}

Silymarin standard (Sigma-Aldrich Company Ltd.) was purchased from VWR International (East Grinstead, West Susses, UK).

\section{Experimental animals}

Female albino Wistar rats weighing $150 \pm 20$ g were obtained from the Nile Company for Pharmaceuticals and Chemical Industries, Cairo, Egypt. Animals were kept in plastic cages and under good ventilation and illumination conditions and allowed free access to tap water and food. 
All experimental protocols were approved by "Medical Research Ethics Committee", National Research Centre, Al Buhouth St., DokkiCairo, Egypt, No. 17-043

Preparation of Silybum mariannum seeds oil and Silybum mariannum seeds extract (Silymarin)

\section{Extraction of Silybum mariannum seeds oil}

About $500 \mathrm{~g}$ of finely powdered seeds were extracted using $n$-hexane for $15 \mathrm{~min}$. Ultrasonic probe with a tip diameter of $20 \mathrm{~mm}$ was employed for direct sonication (the horn tip position inside the extraction vessel was $1 \mathrm{~cm}$ under the solvent level). Extraction was carried out using an Ultrasonic Processor UP400S (400 watts, 24 $\mathrm{kHz}$, Hielscher). Extraction was carried for (15 min) at room temperature (temperature was monitored by a thermocouple inside extraction mixture by using an ice cooling bath around the extraction vessel to keep the temperature constant at $25{ }^{\circ} \mathrm{C} \pm 5{ }^{\circ} \mathrm{C}$ ). After extraction, the extract was centrifuged at $4000 \mathrm{rpm}$.

The supernatant was evaporated under vacuum at $40{ }^{\circ} \mathrm{C}$ to a constant weight and yellow colored residual oil was dried over anhydrous sodium sulfate.

\section{Preparation of unsaponifiable matter}

S. marianum seeds oil ( $1.45 \mathrm{~g})$ was dissolved in boiling acetone $(100$ $\mathrm{ml}$ ), cooled and the amorphous formed precipitate was separated out. The acetone soluble fraction was saponified $(\mathrm{N} / 2$ alc. $\mathrm{KOH})$ and the unsaponifiable matter $(0.30 \mathrm{~g})$ was separated [20].

\section{Preparation of saponifiable matter (fatty acids)}

The aqueous alkaline solution left after the separation of the unsaponifiable matters was acidified with $5 \%$ Sulphuric acid $\left(\mathrm{H}_{2} \mathrm{SO}_{4}\right)$ and the liberated fatty acids were extracted with diethyl ether till exhaustion. The ether extracts containing the free fatty acids were combined, washed with distilled water $(2 \times 50 \mathrm{ml})$ till free from acidity and dehydrated over anhydrous sodium sulphate and then filtered [20]. The solvent was evaporated to dryness under reduced pressure. The weight of the residue was $0.56 \mathrm{~g}$.

\section{Preparation of fatty acid methyl esters}

$0.56 \mathrm{~g}$ of the fatty acid fraction was methylated by dissolving in 10 $\mathrm{ml}$ methanol and $5 \mathrm{ml}$ of boron trifluoride $\left(\mathrm{BF}_{3}\right)$. The mixture was refluxed for $5 \mathrm{~min}$ on a boiling water bath. The mixture was cooled and the methanol was evaporated under reduced pressure. The residue was diluted with $20 \mathrm{ml}$ distilled water and then extracted with diethyl ether $(5 \times 30 \mathrm{ml})$. The combined ethereal extracts were washed with distilled water till neutral to litmus paper, dried over anhydrous sodium sulphate, filtered and evaporated under reduced pressure till dryness [20]. The weight of the residue was $0.51 \mathrm{~g}$ representing $51 \%$ of the total lipoidal matter. The fatty acids methyl esters were subjected to gas chromatography-mass spectrometry (GC-MS) analysis.

\section{Gas chromatography-mass spectrometry analysis of the unsaponifiable matter}

GC-MS analysis of the unsaponifiable matter was carried out using gas chromatography-mass spectrometry, TRACE GC Ultra Gas Chromatographs (THERMO Scientific Corp., USA), coupled with a thermo mass spectrometer detector (ISQ Single Quadrupole Mass Spectrometer). The GC-MS system equipped with a TG-5MS column ( $30 \mathrm{~m} \times 0.25 \mathrm{~mm}$ i.d., $0.25 \mu \mathrm{m}$ film thickness). The injected volume was $0.2 \mu \mathrm{l}$ of diluted sample $(1: 10$ hexane, v/v). Analysis was carried out using helium as carrier gas at a flow rate of $1.0 \mathrm{ml} / \mathrm{min}$ and a split ratio of $1: 10$ using the following temperature program: $50{ }^{\circ} \mathrm{C}$ for $3 \mathrm{~min}$; rising at $5.0^{\circ} \mathrm{C} / \mathrm{min}$ to $300^{\circ} \mathrm{C}$ and held for $20 \mathrm{~min}$. The injector and detector were held at $280^{\circ} \mathrm{C}$. Mass spectra were obtained by electron ionization (EI) at $70 \mathrm{eV}$, using a spectral range of $\mathrm{m} / \mathrm{z} 40-450$.

\section{Gas chromatography-mass spectrometry analysis of the fatty acids methyl esters}

GC-MS analysis of the fatty acids methyl esters was carried out on the same device used for the unsaponifiable matter with the same injection volume, flow rate, split ratio, and carrier gas. However, temperature program was as follow: $80^{\circ} \mathrm{C}$ for $1 \mathrm{~min}$; rising at 4.0 ${ }^{\circ} \mathrm{C} / \mathrm{min}$ to $300^{\circ} \mathrm{C}$ and held for $1 \mathrm{~min}$. The injector and detector were held at $240{ }^{\circ} \mathrm{C}$. Mass spectra were obtained by electron ionization (EI) at $70 \mathrm{eV}$, using a spectral range of $\mathrm{m} / \mathrm{z}$ 40-450.

\section{Silymarin extraction}

The marc left after defatting was then thoroughly extracted using ethyl acetate, extraction was carried out using an ultrasonic probe with a tip diameter of $20 \mathrm{~mm}$ (the horn tip position inside the extraction vessel was $1 \mathrm{~cm}$ under the solvent level). Extraction was carried out using an Ultrasonic Processor UP 400S (400 watts, 24 $\mathrm{kHz}$, Hielscher), direct sonication for (15 $\mathrm{min}$ ) at room temperature (temperature monitored by a thermocouple inside extraction mixture by using an ice cooling bath around the extraction vessel to keep the temperature constant at $25^{\circ} \mathrm{C} \pm 5^{\circ} \mathrm{C}$ ) [21]. After extraction, the collected extract was filtered throughout a Fisher brand QL100, $150 \mathrm{~mm}$ filter paper, then the supernatant was evaporated till dryness under reduced pressure at $45^{\circ} \mathrm{C}$, weighed and stored at -18 ${ }^{\circ} \mathrm{C}$ for high-performance liquid chromatography (HPLC) analysis.

\section{Preparation of standards}

A methanolic solution of standard silymarin $(0.7 \mathrm{mg} / \mathrm{ml})$ was used to understand the chromatographic behaviour of the flavonolignan components of silymarin in analytical conditions.

\section{High-performance liquid chromatography device specifications}

HPLC (Agilent 1100 series) was used to determine the chemical composition of each extract as well as the standard silymarin, equipped with G1315 B diode array detector (DAD), G1313A Autosampler, G1311A Quaternary Pump, G1322A Vacuum Degasser, G1321A Fluorescent Detector, G1316A Column Comp. The control system and data acquiring system was installed with Agilent Chemo station for LC system.

\section{High-performance liquid chromatography analysis}

S. marianum seeds extract and standard silymarin was injected separately to Semi-prep HPLC for analysis using different proportional of $\mathrm{H}_{2} \mathrm{O}$ and methanol as mobile phase.

The mobile phase used was 90:10:1 methanol: $\mathrm{H}_{2} \mathrm{O}$ : formic acid [solvent $\mathrm{A}$ ] and $\mathrm{H}_{2} \mathrm{O}$ (containing $0.1 \%$ formic acid) [solvent $\mathrm{B}$ ] at a flow rate of $0.5 \mathrm{ml} / \mathrm{min}$, the oven was set at $\sim 25^{\circ} \mathrm{C}$. Injection volume was $5 \mu$ l. Detection was carried out by monitoring the absorbance signals at $288 \mathrm{~nm}$.

\section{Radiation processing}

The whole body of the examined rats was exposed to $\gamma$-irradiation using ${ }^{137} \mathrm{Cs}$, biological irradiator source $(\gamma$-Cell-40), located at the National Centre for Radiation Research and Technology (NCRRT), Egypt. The cesium source provides a dose rate of $0.43 \mathrm{~Gy} / \mathrm{min}$ at the time of the experiment. The whole body of animals was exposed to fractionated dose of gamma-rays (4 GyX 2).

\section{Experimental design}

After adaptation period for two weeks, animals were divided to six groups, each of eight rats. Group 1 (G1): control, non-irradiated rats. Group 2 (G2): the whole body of rats was exposed to fractionated dose of $\gamma$-radiation 4 Gy X 2 (four days interval). Group 3 (G3): rats orally received S. marianum seeds extract, $100 \mathrm{mg} / \mathrm{kg}$ body weight (b. wt.) [22] daily for 12 consecutive days. Group 4 (G4): rats orally received $S$. marianum seeds extract, $100 \mathrm{mg} / \mathrm{kg}$ b. wt. daily for 12 consecutive days and the whole body of rats was exposed to fractionated dose of $\gamma$ radiation 4 Gy X 2 (at $4^{\text {th }}$ and $8^{\text {th }}$ day of treatment). Group 5 (G5): rats orally received $S$. marianum seeds oil fraction, $0.5 \mathrm{ml} / \mathrm{kg} \mathrm{b}$. wt. daily for 12 consecutive days. Group 6 (G6): rats orally received S. marianum seeds oil fraction, $0.5 \mathrm{ml} / \mathrm{kg} \mathrm{b}$. wt. daily for 12 consecutive days and the whole body of rats was exposed to fractionated dose of $\gamma$-radiation $4 \mathrm{~Gy}$ $\mathrm{X} 2$ (at $4^{\text {th }}$ and $8^{\text {th }}$ day of treatment). Rats were sacrificed at $13^{\text {th }}$ day of treatment or after $4 \mathrm{~d}$ from the second exposure of $\gamma$-irradiation.

\section{Biochemical analysis}

Blood samples were collected by cardiac puncture under diethyl ether anesthesia, and then serum was obtained by centrifugation at 
$3000 \mathrm{rpm}$ for $15 \mathrm{~min}$. Heart and brain were quickly excised from the rats, washed in ice-cold saline and homogenized $(1: 5 \mathrm{w} / \mathrm{v})$ in $0.25 \mathrm{M}$ sucrose. Lactate dehydrogenase (LDH) serum levels were measured as reported [23], using UV/VIS Spectrophotometer. Creatine kinaseMB (CKMB) serum levels were estimated as reported [24], using commercial kit of ELITECH. Heart and brain reduced glutathione (GSH) levels were estimated according to the method described by Beutler and co-workers [25]. Malondialdehyde (MDA) was estimated as TBARS using UV/VIS Spectrophotometer [26]. Metallothionein (MT) levels were determined by Ag-saturation hemolysate method as reported $[27,28]$, using Thermo Scientific iCE 3000 SERIES Atomic Absorption Spectrometry. A portion of the brain was prepared for dopamine and serotonin estimation as reported [29], using Spectrophotofluoromete.

\section{Statistical analysis}

Student's t-test was applied for the statistical analysis of collected data to determine the probable level of significance. The differences were considered significant at $P \leq 0.05$ [30].

\section{RESULTS}

\section{Fatty acids pattern}

The fatty acid composition of cultivated $S$. marianum seeds oil is recorded in table 1 . Results revealed the presence of a mixture of 10 fatty acids, and it was found that $S$. marianum seeds oil is rich in unsaturated fatty acids, which represent $76 \%$ of the total fatty acids. Linoleic acid and arachidic acid are the major constituents and form $58.20 \%$ and $23.38 \%$ of the total composition, respectively.

Table 1: Fatty acid composition of Silybum marianum seeds oil fraction

\begin{tabular}{llll}
\hline Peak No. & RRT & Relative \% & Constituents \\
\hline 1 & 0.896 & 0.25 & $\mathrm{C}_{16(0)}$ Palmitic acid \\
2 & 0.980 & 0.01 & $\mathrm{C}_{16(1)}$ Palmitoleic acid \\
3 & 0.983 & 0.03 & $\mathrm{C}_{17(0)}$ Heptadecanoic acid \\
4 & 0.985 & 0.04 & $\mathrm{C}_{17(1)}$ Heptadecenoic acid \\
5 & 0.987 & 0.03 & $\mathrm{C}_{18(0)}$ Stearic acid \\
6 & 0.990 & 17.87 & $\mathrm{C}_{18(1)}$ Oleic acid \\
7 & 1 & 58.20 & $\mathrm{C}_{18(2) \text { Linoleic acid }}$ \\
8 & 1.001 & 23.38 & $\mathrm{C}_{20(0)}$ Arachidic acid \\
9 & 1.006 & 0.17 & $\mathrm{C}_{20(1)}$ Eicosenic acid \\
10 & 1.090 & 0.01 & $\mathrm{C}_{22(0)}$ Behenic acid \\
\hline
\end{tabular}

\section{Sterols pattern}

Sterols pattern of the complete unsaponifiable fraction is shown in table 2 . The sterol fraction of the $S$. marianum seeds oil fraction consisted mainly from a mixture of sterols (cholesterol, $\beta$-sitosterol, stigmasterol, campesterol and $\gamma$-sitosterol) and one triterpene $\beta$ amyrin (6\%). $\gamma$-sitosterol is the major component of $S$. marianum sterol and forms (45.81\%) of the total composition.

Table 2: Sterol composition of cultivated Silybum marianum seeds oil fraction

\begin{tabular}{llll}
\hline Peak No. & RRT & Relative \% & Constituents \\
\hline 1 & 0.952 & 15.45 & Cholesterol \\
2 & 0.978 & 4.88 & Campasterol \\
3 & 0.984 & 4.92 & Stigmasterol \\
4 & 1 & 45.81 & $\gamma$-Sitosterol \\
5 & 1.008 & 6.03 & $\beta$-Amyrin \\
6 & 1.013 & 16.66 & $\beta$-Sitosterol \\
\hline
\end{tabular}

\section{Silymarin components}

HPLC profiles of standard silymarin and defatted $S$. marianum seeds extract are presented in fig. 1 and fig. 2; respectively. HPLC analysis showed the presence of seven main active constituents including taxifolin, silydianin, silychristin, diastereomers of silybin (silybin A and B) and diastereomers of isosilybin (isosilybin A and B). Seven principal peaks were observed, with each peak identified as one of the flavolignan constituents of silymarin (table 3).

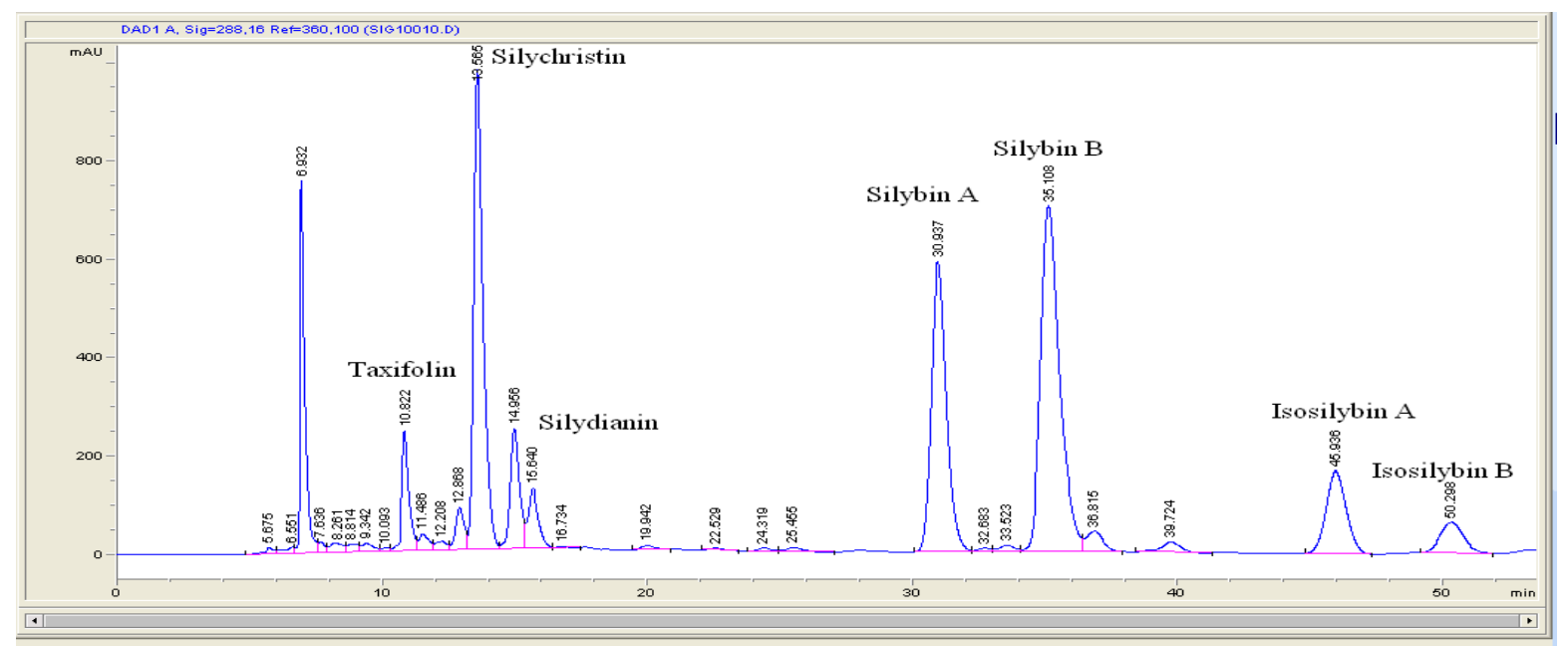

Fig. 1: HPLC chromatogram of standard silymarin 


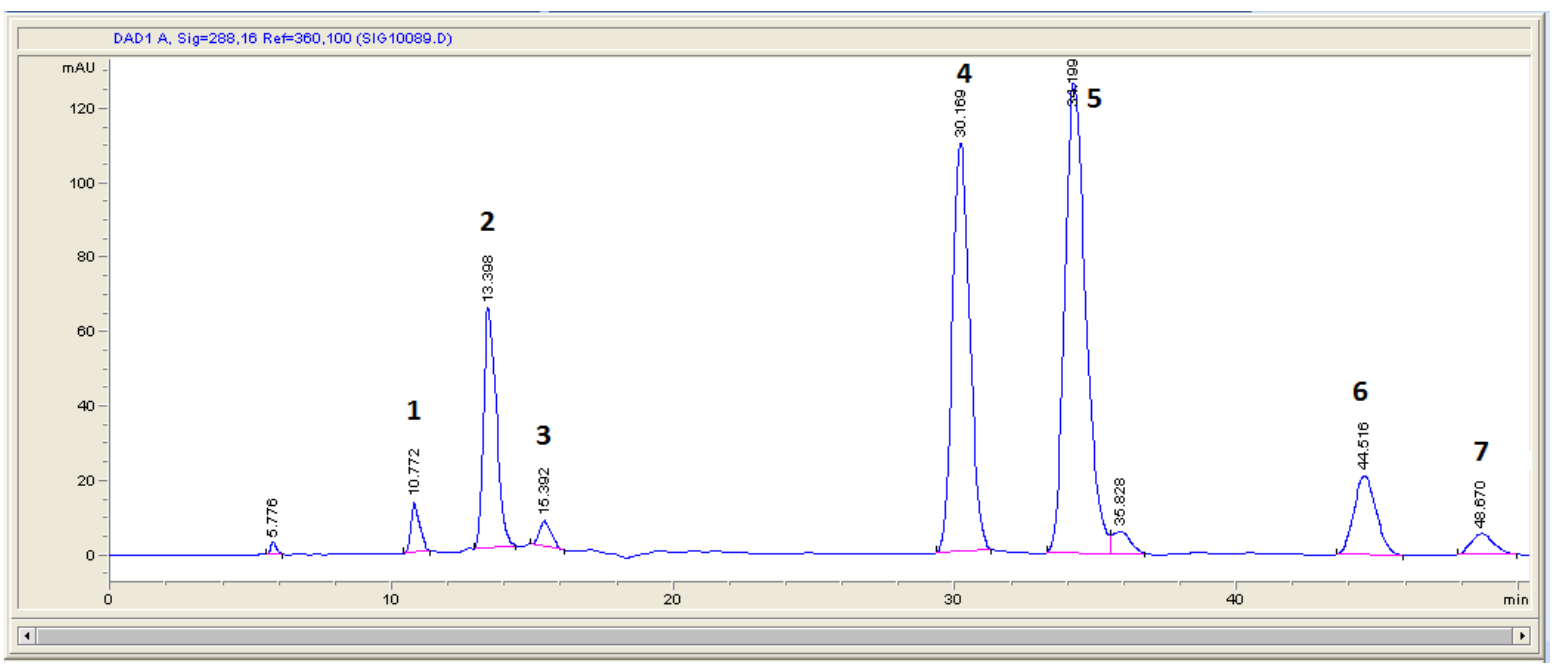

Fig. 2: HPLC chromatogram of cultivated sample of Silybum marianum seeds extract

Table 3: Silymarin composition of silymarin standard and cultivated seeds extract

\begin{tabular}{|c|c|c|c|}
\hline \multirow{2}{*}{ Peak No. } & \multirow[t]{2}{*}{ Compound name } & \multicolumn{2}{|l|}{ Retention time (min) } \\
\hline & & Silymarin standard & Sample \\
\hline 1 & Taxifolin & 10.822 & 10.772 \\
\hline 2 & Silychristin & 13.565 & 13.398 \\
\hline 3 & Silydianin & 15.64 & 15.392 \\
\hline 4 & Silybin A & 30.937 & 30.169 \\
\hline 5 & Silybin B & 35.108 & 34.199 \\
\hline 6 & Iso-Silybin A & 45.936 & 44.516 \\
\hline 7 & Iso-Silybin B & 50.298 & 48.67 \\
\hline
\end{tabular}

\section{Biochemical study}

\section{Compared to non-irradiated control group (Group 1)}

Fractionated dose of $\gamma$-radiation ( 4 Gy X 2, four days interval) significantly elevated lipid peroxidation indicator in heart and brain tissues, MDA (table 4), however, no significant effect was observed on GSH levels of heart and brain tissues (table 5) or MT levels of heart tissues. A significant increase of MT levels in brain tissues was observed (table 6). Irradiated rats also showed a significant decrease of LDH and CKMB serum levels (table 7). Also, a significant decrease in dopamine and serotonin levels of the brain tissues was observed (table 8).

Table 4: Effect of Silybum marianum seeds extract (100 mg/kg b. wt.) and Silybum marianum seeds oil fraction (0.5 ml/kg b. wt.) on heart and brain MDA levels

\begin{tabular}{lll}
\hline Biomarker & MDA (nmol/g) & Brain \\
\hline Organs & Heart & $165.2 \pm 5.273$ \\
\hline G1 & $163.2 \pm 3.760$ & $186.2 \pm 3.212^{*}$ \\
G2 & $202.2 \pm 3.250^{*}$ & $176.2 \pm 8.601$ \\
G3 & $148.1 \pm 11.86$ & $158.5 \pm 5.038^{\#}$ \\
G4 & $139.6 \pm 8.676^{* \#}$ & $177.7 \pm 7.194$ \\
G5 & $161.9 \pm 9.578$ & $135.2 \pm 5.082^{* \#}$ \\
G6 & $165.5 \pm 2.548^{\#}$ & \\
\hline
\end{tabular}

- Each value represents the mean $\pm \mathrm{SE}, \mathrm{n}=8$, *Significant differences from control at $\mathrm{p} \leq 0.05$, \#Significant differences from irradiated group at $\mathrm{p} \leq 0.05$.

Table 5: Effect of Silybum marianum seeds extract $(100 \mathrm{mg} / \mathrm{kg} \mathrm{b}$. wt.) and Silybum marianum seeds oil fraction (0.5 ml/kg b. wt.) on heart and brain GSH levels

\begin{tabular}{lll}
\hline Biomarker & GSH (mg/g) & Brain \\
\hline Organs & Heart & $172.9 \pm 9.237$ \\
\hline G1 & $187.7 \pm 8.644$ & $183.2 \pm 5.830$ \\
G2 & $186.2 \pm 16.06$ & $213.9 \pm 6.472^{*}$ \\
G3 & $226.0 \pm 14.07^{*}$ & $210.4 \pm 7.518^{* \#}$ \\
G4 & $316.4 \pm 12.46^{* \#}$ & $147.9 \pm 1.780^{*}$ \\
G5 & $208.4 \pm 8.614$ & $227.0 \pm 4.249^{* \#}$ \\
\hline
\end{tabular}

- Each value represents the mean $\pm \mathrm{SE}, \mathrm{n}=8$, *Significant differences from control at $\mathrm{p} \leq 0.05$, \#Significant differences from irradiated group at $\mathrm{p} \leq 0.05$. 
Table 6: Effect of Silybum marianum seeds extract (100 mg/kg b. wt.) and Silybum marianum seeds oil fraction (0.5 ml $/ \mathrm{kg} \mathrm{b}$. wt.) on heart and brain MT levels

\begin{tabular}{lll}
\hline Biomarker & MT $(\mathbf{m g} / \mathbf{g})$ & Brain \\
\hline Organs & Heart & $38.67 \pm 1.626$ \\
\hline G1 & $43.87 \pm 2.349$ & $60.44 \pm 1.813^{*}$ \\
G2 & $49.95 \pm 2.698$ & $77.01 \pm 2.813^{*}$ \\
G3 & $62.70 \pm 2.700^{*}$ & $97.38 \pm 6.003^{* \#}$ \\
G4 & $108.5 \pm 5.962^{* \#}$ & $31.92 \pm 1.920^{*}$ \\
G5 & $36.10 \pm 2.154^{*}$ & $65.56 \pm 3.467^{*}$ \\
G6 & $70.52 \pm 3.547^{* \#}$ & \\
\hline
\end{tabular}

- Each value represents the mean $\pm S E, n=8$, *Significant differences from control at $p \leq 0.05$, \#Significant differences from irradiated group at $p \leq 0.05$.

G3 showed a significant increase of GSH and MT levels in both heart and brain tissues, however, no effect was observed on dopamine and serotonin levels in brain tissues or serum levels of LDH and CKMB. Also, no effect was observed on lipid peroxidation indicator in both heart and brain tissues.

G5 showed no effect on MDA levels in heart and brain tissues, but a slight decrease of GSH levels in brain and MT levels in brain and heart was observed. Also, a significant decrease of LDH, dopamine and serotonin levels was observed.

Also compared to non-irradiated control group (G1), G4 showed a significant decrease of MDA levels in heart and brain tissues, while G6 showed a significant decrease of MDA levels in brain tissues. G4 and G6 showed a significant increase of GSH and MT levels in heart and brain tissues. On the other hand, G4 and G6 showed a reduction in serum LDH and CKMB levels. Results also showed a significant increase of dopamine levels in G4.

\section{Compared to irradiated control group (Group 2)}

G4 and G6 showed significant reduction of MDA levels and significant increase of GSH levels in both heart and brain tissues. G6 showed a significant increase of MT levels of heart tissues. G4 showed significant reduction of serum levels of LDH and CKMB, in addition, elevation in dopamine and serotonin levels of brain tissues was observed. On the other hand, G6 showed elevation in dopamine levels, however, no significant effect was observed on serum levels of LDH and CKMB or serotonin levels of brain tissues.

Table 7: Effect of Silybum marianum seeds extract $(100 \mathrm{mg} / \mathrm{kg}$ b. wt.) and Silybum marianum seeds oil fraction $(0.5 \mathrm{ml} / \mathrm{kg} \mathrm{b.} \mathrm{wt.)} \mathrm{on} \mathrm{serum}$ levels of LDH and CKMB

\begin{tabular}{lll}
\hline Biomarker & LDH (U/l) & CKMB (U/I) \\
\hline G1 & $1676 \pm 102.2$ & $154.3 \pm 11.95$ \\
G2 & $1163 \pm 102.4^{*}$ & $76.38 \pm 2.025^{*}$ \\
G3 & $1971 \pm 180.1$ & $156.2 \pm 12.71$ \\
G4 & $804.2 \pm 44.69^{* \#}$ & $56.50 \pm 4.811^{* \#}$ \\
G5 & $1168 \pm 110.5^{*}$ & $179.0 \pm 12.32$ \\
G6 & $1390 \pm 61.62^{*}$ & $84.34 \pm 2.936^{*}$ \\
\hline
\end{tabular}

-Each value represents the mean $\pm S E, n=8$, ${ }^{*}$ Significant differences from control at $\mathrm{p} \leq 0.05$, "Significant differences from irradiated group at $\mathrm{p} \leq 0.05$.

Table 8: Effect of Silybum marianum seeds extract $(100 \mathrm{mg} / \mathrm{kg} \mathrm{b.} \mathrm{wt.)} \mathrm{and} \mathrm{Silybum} \mathrm{marianum} \mathrm{seeds} \mathrm{oil} \mathrm{fraction}(0.5 \mathrm{ml} / \mathrm{kg} \mathrm{b.} \mathrm{wt.)} \mathrm{on}$ dopamine and serotonin levels

\begin{tabular}{lll}
\hline Biomarker & Dopamine $(\mathbf{n g} / \mathbf{g})$ & Serotonin $(\boldsymbol{\mu g} / \mathbf{g})$ \\
\hline G1 & $66.53 \pm 1.074$ & $7.200 \pm 0.208$ \\
G2 & $38.80 \pm 1.804^{*}$ & $3.300 \pm 0.265^{*}$ \\
G3 & $70.40 \pm 6.052$ & $6.207 \pm 0.306$ \\
G4 & $85.27 \pm 4.321^{* \#}$ & $7.247 \pm 0.653^{\#}$ \\
G5 & $43.77 \pm 2.486^{*}$ & $3.740 \pm 0.151^{*}$ \\
G6 & $65.74 \pm 3.282^{\#}$ & $4.046 \pm 0.252^{*}$ \\
\hline
\end{tabular}

-Each value represents the mean $\pm \mathrm{SE}, \mathrm{n}=8$, *Significant differences from control at $\mathrm{p} \leq 0.05$, \#Significant differences from irradiated group at $\mathrm{p} \leq 0.05$.

\section{DISCUSSION}

$\gamma$-radiation exposure increases generation of ROS in different tissues [5]. Increasing of ROS may be involved in atherosclerosis, myocardial ischemia/reperfusion injury and heart failure [31]. High doses of radiation applied to the heart during radiotherapy used in breast cancer [32, 33], Hodgkin's disease [34] or childhood cancers [35], increases cardiovascular malfunctions incidence and mortality. It has been suggested that persistent changes in oxidative metabolism as a result of ionizing radiation, ultimately leads to inflammation and cardiovascular disease [31,36]. The elevation in MDA levels in heart and brain tissues, after $\gamma$-radiation exposure, indicates the oxidative stress due to lipid peroxidation process. Epidemiological data indicates an association between increased risks of cardiovascular disease and enhanced oxidative stress in populations exposed to ionizing radiation [37-41]. Treatment of $\gamma$ - radiation damage effect using $S$. marianum seeds extract and its oil fraction led to an elevation in GSH and MT levels in heart and brain tissues. MT has an important role as a free radical scavenger [42]. Consequently, MT can protect from $\gamma$-radiation damage. Galhardi and co-workers [19] demonstrated the protective effect of silymarin on the antioxidant defence systems in the brain of rats, inducing an increase of glutathione, ascorbic acid and superoxide dismutase activity, with decreased protein oxidation in hippocampus and cortex tissues. Furthermore, silybin prevented the accumulation of lipid peroxide and the decrease of the antioxidant glutathione in the hippocampus, indicating the protective effect of silybin against $\beta$ amyloid neurotoxicity, by regulating oxidative stress in the brain [43]. Also, silymarin was reported to induce the increase of GSH content in the cell and the inhibition of lipid peroxidation where the structure of the phenolic ring of flavonolignans showed antioxidant effect [44]. Furthermore, Fu and co-workers [45] demonstrated the 
in vitro protective effect of silybin and its analogues on DNA damage, which is correlated to their ability to scavenge free radical induced by X-ray exposure.

Despite the oxidative stress induced by $\gamma$-radiation, as revealed by increased lipid peroxidation, we observed a reduction in serum levels of LDH and CKMB at $\gamma$-radiation dose of $4 \mathrm{~Gy} \mathrm{X} 2$. Meanwhile, a reduction in serum levels of $\mathrm{LDH}$ and CKMB of irradiated rats due to $S$. marianum seeds extract treatment was observed, compared to irradiated rats, demonstrating its radio protective effect on the heart. S. marianum seeds oil fraction exhibited a depletion effect on dopamine and serotonin levels whereas there was an improvement in the dopamine level in the treated irradiated rats with $S$. marianum seeds oil fraction. On the other hand, dopamine and serotonin levels gave positive results via $S$. marianum seeds extract or $S$. marianum seeds oil fraction treatment for irradiated rats. In the case of pharmacological stress caused by methamphetamine treatment, silibinin attenuated the decreases of dopamine levels in the prefrontal cortex and serotonin levels in the hippocampus [46]. Silymarin showed an antioxidant effect in the central nervous system, being able to cross the blood-brain barrier [47]. The antioxidant capacity of silymarin against peroxyl radicals reduced in hippocampus and cortex of young rats and also in the hippocampus of elderly animals. This is due to the potential antioxidant effect of silymarin to change the redox state of the cellular environment, altering the antioxidant defence system [48]. According to Pérez and co-workers [49], $100 \mathrm{mg} / \mathrm{kg}$ b. wt. of silymarin showed neuroprotective effect, also at the same dose silymarin exhibited antidepressant effect [50]; due to acute restraint stress in mice via restoration the antioxidant enzymes.

Raza and co-workers [51] revealed that silymarin may be helpful in slowing down the progress of neurodegeneration in focal cerebral ischemia which suggests that neuroprotective potential of silymarin is mediated through its antioxidant and anti-apoptotic properties. According to Ligeret and co-workers [52], silibinin restores GSH levels, diminishes oxidative radical $\left(\mathrm{O}_{2}{ }^{-}\right)$and suppresses lipid peroxidation. Silybin and its analogues offer different ability to repair DNA base pairs against radiation-induced damage [18]. Prabha and co-workers [17] reported that oral administration of silybinin to mice resulted in significant protection against radiationinduced mortality and DNA damage in blood leukocytes.

\section{CONCLUSION}

The present study demonstrated that $S$. marianum seeds extract and its oil fraction has a protective effect against $\gamma$-radiation induced cell damage. The antioxidant activity of $S$. marianum seeds extract and its oil fraction inhibited lipid peroxidation process in heart and brain tissues and induced the production of antioxidant agents (GSH and MT) in the cells of rats exposed to $\gamma$-radiation.

S. marianum seeds extract and its oil fraction has reduced oxidative stress induced by $\gamma$-radiation exposure. Further investigation should be carried out to study the effect of $S$. marianum seeds oil fraction on brain biomarkers; dopamine and serotonin. From the present study, it could be concluded the radioprotective effect of $S$. marianum seeds extract and its oil fraction on heart and brain tissues.

\section{AUTHORS CONTRIBUTION}

All persons who meet authorship criteria are listed as authors, and all authors certify that they have participated sufficiently in the work to take public responsibility for the content, including participation in the concept, design, analysis, writing, or revision of the manuscript.

- Conception and design of the study: Nohair H. Sherif, Asrar M. Hawas, Walid E. Abdallah, Ibrahim A. Saleh, Khaled A. Shams, Faiza M. Hammouda.

- Acquisition of data: Asrar M. Hawas, Ibrahim A. Saleh, Khaled A. Shams

- Analysis and interpretation of data: Nohair H. Sherif, Asrar M. Hawas, Walid E. Abdallah, Ibrahim A. Saleh

- Drafting the manuscript: Nohair H. Sherif, Khaled A. Shams, Faiza M. Hammouda
- Revising the manuscript critically for important intellectual content: Walid E. Abdallah, Asrar M. Hawas, Ibrahim A. Saleh

- Approval of the version of the manuscript to be published: Nohair H. Sherif, Asrar M. Hawas, Walid E. Abdallah, Ibrahim A. Saleh, Khaled A. Shams, Faiza M. Hammouda

\section{CONFLICT OF INTERESTS}

Declared none

\section{REFERENCES}

1. Murdoch CE, Zhang M, Cave AC, Shah AM. NADPH oxidasedependent redox signalling in cardiac hypertrophy, remodelling and failure. Cardiovasc Res 2006;71:208-15.

2. Sawyer DB, Siwik DA, Xiao L, Pimentel DR, Singh K, Colucci WS. Role of oxidative stress in myocardial hypertrophy and failure. J Mol Cell Cardiol 2002;34:379-88.

3. Giordano FJ. Oxygen, oxidative stress, hypoxia, and heart failure. J Clin Invest 2005;115:500-8.

4. Huang KX, Gong JX, Xiong W, Yang LX, Wang F, Tao QF, et al. Preparation of silybin 23-esters and evaluation of their inhibitory ability against LPO and DNA protective properties. Chin Chem Lett 2009;20:1030-3.

5. Anderson FR, Fisher JL, Hara Y, Harris T, Mak BW, Melton DL, et al. Green tea catechins partially protect DNA from $\mathrm{OH}$ radicalinduced strand breaks and base damage through fast chemical repair of DNA radicals. Carcinogenesis 2001;22:1189-93.

6. Maisin JR. Bacq and Alexander award lecture chemical radioprotection: past, present and future prospects. Int J Radiat Biol 1998; 73:443-50.

7. Nair CKK, Parida DK, Nomura T. Radioprotectors in radiotherapy. J Radiat Res 2001;42:21-37.

8. Abbasi BH, Khan MA, Mahmood T, Ahmad M, Chaudhary MF. Shoot regeneration and free-radical scavenging activity in Silybum marianum L. PCTOC 2010;101:371-6.

9. Wellington K, Jarvis B. Silymarin: a review of its clinical properties in the management of hepatic disorders. BioDrugs 2001;15:465-89.

10. Flora K, Hahn M, Rosen H, Benner K. Milk thistle (Silybum marianum) for the therapy of liver disease. Am J Gastroenterol 1998;93:139-43.

11. Gazák R, Walterová D, Kren V. Silybin and silymarin-new and emerging applications in medicine. Curr Med Chem 2007;14:315-38.

12. Pietrangelo A, Montosi G, Garuti C, Contri M, Giovannini F, Ceccarelli D, et al. Iron-induced oxidant stress in nonparenchymal liver cells: mitochondrial derangement and fibrosis in acutely iron-dosed gerbils and its prevention by silybin. J Bioenerg Biomembr 2002;34:67-79.

13. Paulova J, Dvorak M, Kolouch F, Vanova L, Janeckova L. Verification of the hepatoprotective and therapeutic effect of silymarin in experimental liver injury with tetrachloromethane in dogs. Vet Med (Praha) 1990;35:629-35.

14. Sonnenbichler J, Goldberg M, Hane L, Madubunyi I, Vogl S, Zetl I. Stimulatory effect of Silibinin on the DNA synthesis in partially hepatectomized rat livers: non-response in hepatoma and other malign cell lines. Biochem Pharmacol 1986;35:538-41.

15. Sonnenbichler J, Zetl I. Biochemical effects of the flavonolignane silibinin on RNA, protein and DNA synthesis in rat livers. Prog Clin Biol Res 1986;213:319-31.

16. Crocenzi FA, Pellegrino JM, Sanchez EJ, Mottino AD, Garay EA, et al. Effect of silymarin on biliary bile salt secretion in the rat. Biochem Pharmacol 2000;59:1015-22.

17. Prabha T, Amit K, Manjoor A, Mishara KP. Radioprotection of plasmid and cellular DNA and swiss mice by silibinin. Mutat Res 2010;695:55-60.

18. Fu H, Katsumura Y, Lin M, Hata K, Muroya Y, Hatano Y. Fast repair activities towards dGMP hydroxyl radical adducts by silybin and its analogues. J Radiat Res 2008;49:609-14.

19. Galhardi F, Mesquita K, Monserrat JM, Barros DM. Effect of silymarin on biochemical parameters of oxidative stress in aged and young rat brain. Food Chem Toxicol 2009;47:2655-60.

20. Nazif NM. Development of production and application of pigments of certain local plants for food and pharmaceutical 
industries. Pharmacognosy Department, Faculty of Pharmacy, Cairo University, Egypt; 1994.

21. Saleh IA, Vinatoru M, Mason TJ, Abdel-Azim NS, Aboutabl EA, Hammouda FM. Ultrasonic-assisted extraction and conventional extraction of silymarin from Silybum marianum seeds; a comparison. Res J Pharm Biol Chem Sci 2015;6:709-17.

22. El-Gabry MS, Abou-Safi HM, El-Yamany NA, Abdel-Hamid GR. Physiological studies on the efficacy of silymarin as antioxidant against the disorders in some blood constituents induced by irradiation in female rats. EJHM 2003;11:1-14.

23. Pesce A. Lactate dehydrogenase. In: Kaplan A. editor. Clinical Chemistry. Vol 438, St Louis. Toronto: The C. V. Mosby Co. Princeton; 1984. p. 1124-27.

24. Dawson DM, Eppenberger HM, Kaplan NO. Creatine kinase: evidence for a dimeric structure. Biochem Biophys Res Commun 1965;21:346-53.

25. Beutler E, Duron O, Kelly BM. Improved method for the determination of blood glutathione. J Lab Clin Med 1963;61:882-8.

26. Yoshioka T, Kawada K, Shimada T, Mori M. Lipid peroxidation in maternal and cord blood and protective mechanism against activated oxygen toxicity in the blood. Am J Obstet Gynecol 1979;135:372-6.

27. Scheuhammer AM, Cherian MG. Quantification of metallothioneins by a silver-saturation method. Toxicol Appl Pharmacol 1986;82:417-25.

28. Bienengräber $M$, Forderkunz $S$, Klein D, Summer KH. Determination of $\mathrm{Cu}$-containing metallothionein: comparison by Ag saturation assay, thiomolybdate assay and enzymelinked immunosorbent assay. Anal Biochem 1995;228:69-73.

29. Ciarolone AE. Further modification of a fluorometric method for analyzing brain amines. Microchem J 1978;23:9-12.

30. Kirkwood BR. Comparison of two means. In: Kirkwood BR. editor. Essentials of medical statistics. Oxford, England: Blackwell Scientific Publications; 1988. p. 41-45.

31. Takano H, Zou Y, Hasegawa H, Akazawa H, Nagai T, Komuro I. Oxidative stress-induced signal transduction pathways in cardiac myocytes: involvement of ROS in heart diseases. Antioxid Redox Signal 2003;5:789-94.

32. Demirci S, Nam J, Hubbs JL, Nguyen T, Marks LB. Radiationinduced cardiac toxicity after therapy for breast cancer: interaction between treatment era and follow-up duration. Int J Radiat Oncol Biol Phys 2009;73:980-7.

33. Darby S, Hill D, Auvinen A, Barros-Dios JM, Baysson H, Bochicchio $\mathrm{F}$, Deo $\mathrm{H}$, et al. Radon in homes and risk of lung cancer: collaborative analysis of individual data from 13 European case-control studies. Br Med J 2005;330:223-8.

34. Swerdlow AJ, Higgins CD, Smith P, Cunningham D, Hancock BW, Horwich A, et al. Myocardial infarction mortality risk after treatment for Hodgkin disease: a collaborative British cohort study. J Natl Cancer Inst 2007;99:206-14.

35. Tukenova M, Guibout C, Oberlin O, Doyon F, Mousannif A, Haddy N, et al. Role of cancer treatment in long-term overall and cardiovascular mortality after childhood cancer. J Clin Oncol 2010;28:1308-15.

36. Spitz DR, Azzam EI, Li JJ, Gius D. Metabolic oxidation/reduction reactions and cellular responses to ionizing radiation: a unifying concept in stress response biology. Cancer Metastasis Rev 2004;23:311-22.
37. Hauptmann M, Mohan AK, Doody MM, Linet MS, Mabuchi K. Mortality from diseases of the circulatory system in radiologic technologists in the United States. Am J Epidemiol 2003;157:239-48.

38. Howe GR, Zablotska LB, Fix JJ, Egel J, Buchanan J. Analysis of the mortality experience amongst U. S. nuclear power industry workers after chronic low-dose exposure to ionizing radiation. Radiat Res 2004;162:517-26.

39. Ivanov VK. Late cancer and noncancer risks among Chernobyl emergency workers of Russia. Health Phys 2007;93:470-9.

40. McGeoghegan D, Binks K, Gillies M, Jones S, Whaley S. The noncancer mortality experience of male workers at British Nuclear Fuels plc, 1946-2005. Int J Epidemiol 2008;37:506-18.

41. Muirhead CR, O'Hagan JA, Haylock RG, Phillipson MA, Willcock $\mathrm{T}$, Berridge GLC, et al. Mortality and cancer incidence following occupational radiation exposure: third analysis of the National Registry for Radiation Workers. Br J Cancer 2009;100:206-12.

42. Cai L, Satoh M, Tohyama C, Cherian MG. Metallothionein in radiation exposure: its induction and protective role. Toxicology 1999;132:85-98.

43. Lu P, Mamiya T, Lu LL, Mouri A, Zou L, Nagai T, et al. Silibinin prevents amyloid beta peptide-induced memory impairment and oxidative stress in mice. Br J Pharmacol 2009;157:1270-7.

44. Valenzuela A, Guerra R. Protective effect of the flavonoid silybin dihemisuccinate on the toxicity of phenylhydrazine on rat liver. FEBS Lett 1985;181:291-4.

45. Fu H, Lin M, Katsumura Y, Yokoya A, Hata K, Muroya Y, et al. Protective effects of silybin and analogues against X-ray radiation-induced damage. Acta Biochim Sin 2010;42:489-95.

46. Lu P, Mamiya T, Lu L, Mouri A, Niwa M, Kim HC, et al. Silibinin attenuates cognitive deficits and decreases of dopamine and serotonin induced by repeated methamphetamine treatment. Behav Brain Res 2010;207:387-93.

47. Nencini C, Giorgi G, Micheli L. Protective effect of silymarin on oxidative stress in rat brain. Phytomedicine 2007;14:129-35.

48. Jones DP. Redefining oxidative stress. Antioxid Redox Signal 2006;8:1865-79.

49. Pérez HJ, Carrillo SC, García E, Ruiz-Mar G, Pérez-Tamayo R, Chavarría A. Neuroprotective effect of silymarin in a MPTP mouse model of Parkinson's disease. Toxicology 2014;319:38-43.

50. Thakare VN, Dhakane VD, Patel BM. Potential antidepressant-like activity of silymarin in the acute restraint stress in mice: modulation of corticosterone and oxidative stress response in cerebral cortex and hippocampus. Pharmacol Rep 2016;68:1020-7.

51. Raza SS, Khan MM, Ashafaq M, Ahmad A, Khuwaja G, Khan A, et al. Silymarin protects neurons from oxidative stress associated damages in focal cerebral ischemia: a behavioral, biochemical and immunohistological study in Wistar rats. J Neurol Sci 2011;309:45-54.

52. Ligeret H, Brault A, Vallerand D, Haddada Y, Haddad PS. Antioxidant and mitochondrial protective effects of silibinin in cold preservation-warm reperfusion liver injury. J Ethnopharmacol 2008;115:507-14.

\section{How to cite this article}

- Nohair H Sherif, Asrar M Hawas, Walid E Abdallah, Ibrahim A Saleh, Khaled A Shams, Faiza M Hammouda. Potential role of milk thistle seed and its oil extracts against heart and brain injuries induced by $\gamma$-radiation exposure. Int J Pharm Pharm Sci 2017;9(7):52-58. 